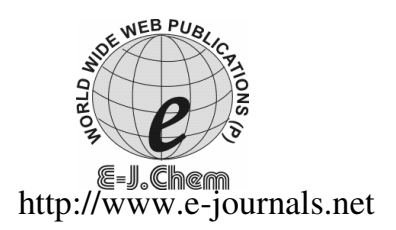

ISSN: 0973-4945; CODEN ECJHAO

E-Journal of Chemistry

2011, 8(4), 1986-1992

\title{
Lipids Characterization and Industrial Potentials of Pumpkin Seeds (Telfairia occidentalis) and Cashew Nuts (Anacardium occidentale)
}

\author{
N.O. EDDY*, J.A. UKPONG ${ }^{\S}$ and E. E. EBENSO \\ *Department of Chemistry, Ahmadu Bello University, Zaria, Nigeria \\ ${ }^{\S}$ Department of Chemistry, University of Uyo, Nigeria \\ Department of Chemistry, North West University (Mafikeng Campus), \\ Private Bag X2046, Mmabatho 2735, South Africa \\ nabukeddy@yahoo.com
}

Received 1 March 2011; Accepted 22 April 2011

\begin{abstract}
Oil from Telfaria occidentalis and Anarcardium occidentale has been extracted and characterized. The lipid content of the Telfaria occidentalis and Anarcardium occidentalis were $58.41 \%$ and $42.15 \%$ respectively. The physicochemical parameters of Telfaria occidentalis and Anarcardium occidentale seeds were; boiling point; $\left(58.90,62.60{ }^{\circ} \mathrm{C}\right)$, melting point; $\left(18.50,21.80{ }^{\circ} \mathrm{C}\right)$, refractive index; $(1.462,1.498)$, specific gravity; $(0.87$, $0.69)$ saponification value; $(91.16,92.57)$ iodine value; $(51.52,47.20)$, acid value; $(0.76,3.74)$ ester value; $(90.40,88.87), \%$ free fatty acid; $(.38,1.88)$ and peroxide value; $(11.75,15.23)$ respectively. Oils from these seeds were found to exhibit the needed potentials for utilization in paint and food industries and as biofuel.
\end{abstract}

Keywords: Telfaria occidentalis, Anarcardium occidentale seeds, Lipid characterization, Industrial potentials

\section{Introduction}

Fats and oils belong to the class of compounds called lipids which account for about $1 / 2$ of the food energy value ${ }^{1}$. The lipids are constituents of all cells and as such have a bodybuilding role ${ }^{2}$. Human body uses lipids to provide energy because $1 \mathrm{~g}$ of fat yields 9 calories, $1 \mathrm{~g}$ of protein yields 4 calories $^{3}$. Some constituents of lipids are incorporated as structural components of the brain and cell membranes and therefore, have an important biological function. In addition, dietary fats carry fat-soluble vitamins A, D, E and K and are sources of anti-oxidants and bioactive compounds. 
Major sources of fat and oil are plant and animal ${ }^{3}$. Most plant oils are derived from oil bearing seeds and nuts. Seeds and nuts are good sources of oil needed for cooking, for the production of soap, cake meal, magarine and as valuable protein supplement for all classes of farm animals. Nuts and seeds are also of value in the production of confectioneries such as cheese, sweets, crisps, sandwiches, cookies and for flavoring foods. They can be roasted, fried or boiled and eaten as snacks; In Nigeria, nuts e.g. groundnuts are used for industrial production of groundnut oil and cake. The oil has better flavour than all other vegetable oils and the cake is used for formulating animal feed or as a snack ${ }^{2}$; nuts and seed flours are incorporated into infant foods such as root and tuber based diets, which are low in protein in order to increase their protein content and improve flavour.

Apart from their food and biochemical utilization, fats and oils are raw materials for the food, coating, paint, pharmaceutical, soap and detergent and cosmetic industries ${ }^{4}$. Recently, the production of biofuel from fats and oils has been advocated ${ }^{1}$. Factors or analytical parameters such as saponification value, iodine value, peroxide value, ester value, acid value have been found to be significant in assessing the various uses in which a given fat or oil can be effective.

Several works has been done on the characterization of fats and oils but literature on their relative importance with regard to their physiochemical parameters are scanty. The present study is aimed at characterizing oil extracted from samples of fluted pumpkin seeds and cashew nuts and to investigate their industrial potentials.

\section{Experimental}

The fluted pumpkin fruits and cashew nuts were purchased randomly from dealers locally in Akwa Ibom State, Nigeria. The samples were stored in black polythene bags and conveyed to laboratory for analysis.

\section{Extraction of oil}

The samples were placed in a Soxhlet extractor and the extractions were done continuously using petroleum ether. The extracted oil was recovered by evaporation, cooled and preserved for further analysis

\section{Determination of the lipid content}

In the determination of the lipid content of the sample, the A.O.A.C recommended method was used ${ }^{5}$. The crude fat was extracted from $4 \mathrm{~g}$ of each sample using Soxhlet extractor with low boiling point $\left(40-60{ }^{\circ} \mathrm{C}\right)$ petroleum ether. The weight of the lipid after evaporating off the solvent represented the weight of the lipid.

$$
\% \text { Lipid }=\frac{\text { Weight of extract }}{\text { Weight of dry sample }} \times 100
$$

\section{Determination of boiling point}

A capillary tube of about 3-4 cm long was sealed at one end and placed in a glass tube with its open end downwards. A little quantity of the oil samples was introduced into the tube with a dropper. The tube was then fastened to a thermometer and immersed in a bath of liquid paraffin used for determination of boiling point. The bath was heated slowly with continuous stirring until a rapid and continuously stream of bubbles evolved from the capillary 
tube and passed through the liquid. The flame was removed and the system was allowed to cool while continuously stirring until a point was reached which the bubbling ceased and the oil started to rise in the capillary tube. The temperature at which the oil just entered the capillary tube was noted as the boiling point of the oil. The procedures were repeated three times and the mean temperatures were recorded.

\section{Determination of melting point}

In the determination of melting point of the oil, the oil samples were left in the refrigerator to solidify and the solidified samples was placed in a capillary tube. The tube was inserted into the hole of the electro thermal melting point apparatus. The temperature of the instrument was set and the instrument was allowed to stand until the lipid samples melted as observed through the lens of the instrument.

\section{Determination of specific gravity}

In the determination of the specific gravity of the oil sample, a washed, dried and weighed density bottle was filled with the oil sample and placed in a water bath for a temperature of $25{ }^{\circ} \mathrm{C}$ to be attainable. The weight of the oil was recorded after which the bottle was emptied, washed and dried again before refilling with water maintained at a temperature of $25{ }^{\circ} \mathrm{C}$. The weight of water at this temperature was recorded and the specific gravity was calculated from the formula,

$$
\text { Specific gravity }=\frac{\text { Weight of the sample in the density bottle }}{\text { Weight of equal volume of water }}
$$

\section{Determination of refractive index}

In the determination of the refractive index of the oil, Abbe 60 refractometer was used. Two drops of the oil sample were placed in the glass prism sample compartment. The instrument was allowed to stand for 10 minutes in order to attain a steady temperature after which the reading of the refractive index was recorded ${ }^{5}$.

\section{Determination of iodine value}

Prior to the determination of the iodine value of the oil, Hanus reagent, potassium iodide and starch solution were prepared as follows; $13.2 \mathrm{~g}$ of Iodine crystals were dissolved in $100 \mathrm{~mL}$ of glacial acetic acid. The solution was put in a water bath until the iodine dissolved. The solution was cooled and $3 \mathrm{~mL}$ of bromine was added to double the halogen content. The solution was stored in a dark cupboard for use. $1 \mathrm{~g}$ of potassium iodide was weighed and dissolved with $20 \mathrm{~mL}$ of distilled water. The solution was made up to the $100 \mathrm{~mL}$ mark and stored in a reagent bottle. The starch solution was also prepared by dissolving $1 \mathrm{~g}$ of soluble starch in $10 \mathrm{~mL}$ of distilled water and made up to mark in a $100 \mathrm{~cm}^{3}$ standard volumetric flask. In the determination of iodine value of the oil, $0.5 \mathrm{~g}$ of each of the oil sample was dissolved in $100 \mathrm{~mL}$ of chloroform contained in a $500 \mathrm{~cm}^{3}$ conical flask. $25 \mathrm{~mL}$ of Hanus solution was added into each flask, stoppered and allowed to stand for 30 minutes in the dark. A blank test was carried out without the samples using exactly the same quantity of chloroform and Hanus solution, stoppered and also allowed to stand for 30 minutes. $15 \mathrm{~cm}^{3}$ of $10 \%$ potassium iodide solution and $10 \mathrm{~mL}$ of distilled water were added to each flask mixed by gentle shaking. The content of the flask was titrated with $0.1 \mathrm{~N} \mathrm{Na}_{2} \mathrm{~S}_{2} \mathrm{O}_{3}$ to pale yellow before the addition of $2 \mathrm{~mL}$ of starch indicator. The titration continued until the blueblack colour was completely discharged. 


\section{Calculation}

$1 \mathrm{~cm}^{3}$ of $0.1 \mathrm{~N} \mathrm{Na}_{2} \mathrm{~S}_{2} \mathrm{O}_{3} \equiv 0.01269 \mathrm{~g}$ of iodine $1.26(\mathrm{a}-\mathrm{b}) / \mathrm{w}, \mathrm{w}=$ weight of the sample, $\mathrm{b}=$ volume of $0.1 \mathrm{~N} \mathrm{Na}_{2} \mathrm{~S}_{2} \mathrm{O}_{3}$ for the sample, $\mathrm{a}=$ volume of $0.1 \mathrm{~N} \mathrm{Na}_{2} \mathrm{~S}_{2} \mathrm{O}_{3}$ for the blank, $1 \mathrm{~cm}^{3}$ of $0.1 \mathrm{Na}_{2} \mathrm{~S}_{2} \mathrm{O}_{3} \equiv 0.01269 \mathrm{~g}$ of $1_{2,} \therefore 1000 \mathrm{~cm}^{3} \equiv 0.01269 \times 1000,12.69 \times 0.1 \mathrm{~N}=1.269$

Determination of saponification value

$2 \mathrm{~g}$ of Each of the oil sample were respectively weighed into the different conical flasks and $25 \mathrm{~mL}$ of ethanedioic potash was added. A blank was prepared by adding the same quality of the ethanedioic potash (without the oil sample) to another flask. All the flasks were boiled in a water bath for 30 minutes with frequent shaking. Two drops of phenolphthalein indicator were added to each flask and titrated with $0.5 \mathrm{M} \mathrm{HCl}$ with vigorous shaking to the end point.

\section{Calculation}

$1 \mathrm{~cm}^{3}$ of $0.5 \mathrm{M}$ of $\mathrm{HCl} \equiv 0.02805 \mathrm{~g} \mathrm{KOH}, \therefore 1000 \mathrm{~cm}^{3} \equiv 0.02805 \times 1000=28.05, \mathrm{SV}$ $($ Saponification value $)=(\mathrm{B}-\mathrm{S}) 28.05 / \mathrm{w}$; where $\mathrm{B}=$ Average blank titre, $\mathrm{S}=$ Average sample titre and $\mathrm{W}=$ weight of the sample

\section{Determination of acid value}

$2 \mathrm{~g}$ Each of the different oil samples were weighed and were added to $25 \mathrm{~cm}^{3}$ of $\mathrm{CCl}_{4}$ in different conical flasks. Two drops of phenolphthalein indicator were then added to the mixture. A similar titration was performed without the sample to determine the blank and titration was carried out with $0.1 \mathrm{~N}$ alcoholic potash until the colour change occurred in the different conical flasks

\section{Calculation}

Av $=($ sample titre - blank) $0.1 \times 56.1 / \mathrm{w}$. where $\mathrm{W}=$ weight of sample. Estimation of ester value, The ester value of the oil was calculated from the equation; $\mathrm{EV}=\mathrm{SV}-\mathrm{AV}$; where $\mathrm{EV}$ is the ester value, $\mathrm{SV}$ is the saponification value and $\mathrm{AV}$ is the acid value.

\section{Determination of free fatty acid value}

$25 \mathrm{~mL}$ of ethanol was added to $1.5 \mathrm{~g}$ of each oil sample contained in the different conical flasks. The mixture was brought to boil in a water bath then cooled. Two drops of phenolphthalein indicator were added to the solution. $0.1 \mathrm{M} \mathrm{NaOH}$ was used to titrate the mixture with constant shaking for proper mixing.

$$
\% \mathrm{FFA}=\frac{\mathrm{V} \times 0.0282}{\text { Weight of the sample }} \times 100
$$

Where $\mathrm{V}=$ titre value, $\mathrm{W}=$ weight of the sample also $1 \mathrm{~cm}^{3}$ of $0.1 \mathrm{M} \mathrm{NaOH}$ contains 0.0282 of oleic acid.

\section{Determination of peroxide value}

$2 \mathrm{~g}$ Each of the oil samples were respectively weighed into different conical flasks and $15 \mathrm{~mL}$ of the mixture of $\left(\mathrm{CH}_{3} \mathrm{COOH}-\mathrm{CHCl}_{3}\right)$ in the ratio of $3: 2$ respectively was added to the oil sample. $0.5 \mathrm{~mL}$ of saturated potassium iodide was added to each conical flask and allowed to stand for 5 minutes, thereafter; $15 \mathrm{~mL}$ of distilled water was added and titrated with $0.1 \mathrm{~N} \mathrm{Na}_{2} \mathrm{~S}_{2} \mathrm{O}_{3}$ until the yellowish colour almost disappeared, then $0.5 \mathrm{~mL}$ of starch was added and the titration continued to a colourless end-point.

\section{Calculation}

$$
\text { Peroxide value }=\frac{1000\left(\mathrm{~V}_{2}-\mathrm{V}_{1}\right) \mathrm{T}}{\mathrm{M}}
$$


Where $\mathrm{M}=$ mass of oil taken $(2 \mathrm{~g}), \mathrm{V}_{2}=$ volume of $0.1 \mathrm{~N} \mathrm{Na}_{2} \mathrm{~S}_{2} \mathrm{O}_{3}, \mathrm{~V}_{1}=$ volume of $0.1 \mathrm{~N}$ blank and $\mathrm{T}=$ normality of $\mathrm{Na}_{2} \mathrm{~S}_{2} \mathrm{O}_{3}(0.1 \mathrm{~N})$

\section{Results and Discussion}

The lipid content of fluted pumpkin seed $(58.41 \%)$ was higher than the lipid content of cashew nut $(42.15 \%)$. Longe et. $a l^{6}$ and Akwaowo et. $a l^{7}$ have documented that fluted pumpkin seeds contain $53.0 \%$ and $56.24 \%$ lipid respectively. The high lipid content of fluted pumpkin seed in this work $(58.41 \%)$ closely agrees with those reported by these earlier workers. Achinewhu ${ }^{8}$ documented the lipid content of cashew nut as $48.0 \%$ while Fetuga et. $a l^{9}$ reported the lipid content of cashew nut as $48.1 \%$. These values are slightly higher than the value obtained in this study $(42.15 \%)$, the difference may be due to species related factors or seasonal differences. The values obtained for the lipid content of both seeds are comparable to the range of values $(42.10-70.0 \%)$ reported for some oil bearing seeds ${ }^{10,11}$. The high protein and lipid contents of these seeds have confirmed earlier reports that these seeds are potentially good sources of protein and lipids ${ }^{7,12}$. The physiological fuel value that can be obtained from consumption of $1 \mathrm{~g}$ lipid is $9 \mathrm{kcal}$ implying that the consumption of $100 \mathrm{~g}$ of cashew nut will liberate $42.15 \times 9=379.35 \mathrm{kcal}$ while $100 \mathrm{~g}$ of fluted pumpkin seed will liberate $58.41 \times 9=525.69$ $\mathrm{kcal}$ of energy. The recommended daily intake of lipid is $80-100 \mathrm{~g}$ and out of this value, plant lipids containing unsaturated fatty acids should not be less than $20-25 \mathrm{~g}$ per day ${ }^{13}$. Therefore both seeds are excellent sources of lipids. The results of the physicochemical parameters of oil from fluted pumpkin and cashew seeds were as shown in Table 1.

Table 1. Physicochemical parameters of the oil samples

\begin{tabular}{lll}
\hline \multicolumn{1}{c}{ Physicochemical parameters } & \multicolumn{1}{c}{ Fluted pumpkin seed } & \multicolumn{1}{c}{ Cashew nut } \\
\hline Boiling point, ${ }^{\circ} \mathrm{C}$ & $58.90 \pm 0.21$ & $62.60 \pm 0.05$ \\
Melting point, ${ }^{\circ} \mathrm{C}$ & $18.50 \pm 0.15$ & $21.80 \pm 0.23$ \\
Refractive index & $1.462 \pm 0.20$ & $1.498 \pm 0.12$ \\
Specific Gravity & $0.87 \pm 0.05$ & $0.69 \pm 0.04$ \\
Saponification Value, $\mathrm{mgKOH} / \mathrm{g}$ & $91.16 \pm 3.63$ & $92.57 \pm 1.24$ \\
Iodine Value, $\mathrm{gI}_{2} / 100 \mathrm{~g}$ & $51.52 \pm 1.12$ & $47.20 \pm 0.21$ \\
Acid Value, $\mathrm{mgKOH} / \mathrm{g}$ & $0.76 \pm 0.09$ & $3.74 \pm 0.36$ \\
Ester Value, $\mathrm{mgKOH} / \mathrm{g}$ & $90.40 \pm 2.83$ & $88.87 \pm 4.05$ \\
\%FFA (as oleic acid) & $0.38 \pm 0.38$ & $1.88 \pm 0.21$ \\
Peroxide value & $11.75 \pm 0.69$ & $15.23 \pm 0.39$ \\
\hline
\end{tabular}

*Mean of three determinations \pm Standard Deviation

The boiling points of fluted pumpkin seed and cashew nut lipids were $62.60{ }^{\circ} \mathrm{C}$ and $58.90{ }^{\circ} \mathrm{C}$ respectively. The boiling points of the oils show no significant difference $(\mathrm{P}>0.05)$. The boiling points are comparable to the values obtained in literature for some oil seeds ${ }^{14}$ but lower than the boiling point of the oils studied ${ }^{15}$.

The melting points of fluted pumpkin seed $\left(18.50{ }^{\circ} \mathrm{C}\right)$ and cashew nut $21.80{ }^{\circ} \mathrm{C}$ were comparable to each other and also comparable with the melting point range $\left(24.2-42.3{ }^{\circ} \mathrm{C}\right)$ reported for some seed oils ${ }^{16,17}$. The melting point of the seed oils is an advantage in cold cream manufacture. The melting point of cashew nut oil makes it valuable confectionery oil just like coconut oil $^{17}$. The lower the melting point of seed oil, the better the oil is for making oil creams ${ }^{18}$.

The specific gravity of oil extracted from cashew nuts (0.69) was lower than the specific gravity of oil extracted from fluted pumpkin seeds (0.87) and these values are not comparable $(\mathrm{P} \leq 0.05)$. These values compares well with the values for edible vegetable oils. These oils can thus serve edible purposes when they are purified. 
The refractive index of cashew nuts oil (1.498) and that of fluted pumpkin seeds oil (1.462) at $40{ }^{\circ} \mathrm{C}$ were comparable to each other. The values of the refractive index of oils are closely related to their molecular masses.

The saponification value of fluted pumpkin seed oil $(91.16 \mathrm{mg} / \mathrm{KOH} / \mathrm{g})$ was comparable to the saponification value of cashew nut oil $(92.57 \mathrm{mg} \mathrm{KOH} / \mathrm{g})$ and there was no significant difference $(\mathrm{P}>0.05)$ between the saponification values of the two oil samples. These values compares favourably with the saponification values reported for some seed oils ${ }^{19}$. The lower the saponification values of the oil, the better the quality of the oil in production of soaps and detergents ${ }^{1}$. The value obtained for the saponification value of these oils are high when compared with values reported for oil commonly used in soap making implying that these oils may not be suitable for soap and detergent making.

The iodine value of fluted pumpkin oil $\left(51.52 \mathrm{~g} \mathrm{I}_{2} / 100 \mathrm{~g}\right)$ was higher than the iodine value of cashew nut oil $\left(47.20 \mathrm{I}_{2}\right)$ and there was a significant difference between the iodine values of the seeds $(\mathrm{P}<0.05)$. The iodine values are comparable with values reported for some oilbearing seeds. The oils with iodine values less than 130 are regarded as non-drying oils and are suitable for paint making, therefore fluted pumpkin seed oil and cashew nut oil may be used for paint making with respect to their low iodine values and their non-drying properties. The iodine values of the two oil samples also fall within the range $\left(6-150 \mathrm{~g} \mathrm{I}_{2} / 100 \mathrm{~g}\right)$ required for making edible oils by CODEX, therefore the oil samples may be purified and used for edible purposes. The low iodine values of the oils also reduce the risk of oxidative rancidity.

The acid value of cashew nut oil $(3.74 \mathrm{mg} \mathrm{KOH} / \mathrm{g})$ was higher than the acid value of pumpkin seed oil $(0.76 \mathrm{mg} \mathrm{KOH} / \mathrm{g})$ and there was a significant difference $(\mathrm{P}<0.05)$ between the acid values of the two oil samples. The acid values are comparable to the range of values of $(0.31 \mathrm{mgKOH} / \mathrm{g}-3.25 \mathrm{mgKOH} / \mathrm{g})$ reported for some oil-bearing seeds ${ }^{20}$. The ester value of fluted pumpkin seed oil $(90.40 \mathrm{mgKOH} / \mathrm{g})$ was comparable with the ester value of the cashew nut oil $(88.87 \mathrm{mg} / \mathrm{KOH} / \mathrm{g})$, since their saponification values are comparable.

The percentage free fatty acid value of fluted pumpkin seed oil $(0.38 \%)$ was lower than the percentage free fatty acid of cashew nut oil (1.88\%). However, these values were comparable to values reported for other oil bearing seeds ${ }^{20}$. The low acid and percentage free fatty acid values of both oil samples suggests that the oils are in good condition to be used for edible purposes. The percentage free fatty acid values of the oils are lower than the maximum limit of $5 \%$ for high - grade palm oil in Nigeria ${ }^{21}$.

The peroxide values of fluted pumpkin (11.75) were lower than the peroxide value of cashew nut oil (15.23). The observed peroxide values for the seed oil samples are comparable to the range $(5.0$ - 150) for some edible seed oils e.g. soybean oil and coconut oil. The low peroxide values of the oil samples is an indication that the oils are stable and may not be susceptible to oxidative rancidity since they are produced from fresh seeds.

The biofuel potential of an oil can be calculated from the Batel et $a l^{22}$ equation, $\mathrm{H}_{\mathrm{v}}=47.645-4.1871-38.31 \mathrm{~S}$; Where I and $\mathrm{S}$ are the iodine and saponification value of the oil. Substituting for the values of $\mathrm{S}$ and I from Table 1, the biofuel potentials of fluted pumpkin and cashew seeds are $-3660.4086 \mathrm{~kJ} / \mathrm{kg}$ and $-3696.61581 \mathrm{~kJ} / \mathrm{kg}$ respectively. This implies that the biofuel potentials of oil from fluted pumpkin seed is slightly greater than that of cashew nut. These values compare well with values reported for oil from other seeds ${ }^{1}$.

\section{Conclusion}

The study revealed that cashew nut and fluted pumpkin seeds are oil bearing seeds and the physicochemical parameters of their oil are comparable. Their food value is high when compare to other oil bearing seeds. The industrial potential of these seeds oil include utilization in paint and coating industries, biofuel manufacturing and food industries. 


\section{References}

1. $\quad$ Ekop A S and Eddy N O, Glo J Pure Appl Sci., 2006, 12(1), 65-67.

2. Enwere N J, Foods of Plant Origin AFRO - ORBIS LTD Nsukka, Nigeria, 1998, 32- 52.

3. Eneobong $\mathrm{H} \mathrm{N}$, Eating right; A nutritional guide. Nigeria: Zoompter Print Communications Ltd., Calabar, Nigeria University of Calabar Press, 2001,

4. Woollatt E, The manufacture of Soaps, other Detergents and Glycerin: $2^{\text {nd }}$ Edition Ellis Harwood Publishers Chichester England, 1985.

5. Association of Official Analytical Chemists: Official Methods of Analysis $15^{\text {th }}$ Ed., D C Washington, 1995.

6. Longe O G, Farinu G O and Fetuga B L, J Agric and Food Chem., 1983, 31(5), 989-992.

7. Akwaowo E U, Ndon B A and Etuk E U, Food Chem., 2000, 70, 235-240.

8. Longe G O, Farinu G O and Fetuga B L, J Agric Food Chem., 1983, 31(5), 989-992

9. Fetuga B L, Babatunde G M and Oyenuga V A, J Sci Food Agric., 1974, 24(12), 1515-1523.

10. Jameison G S, Vegetable fats and oils, their Chemistry, Production and Utilization for edible, medical and technical purpose. $2^{\text {nd }}$ Ed., Reinhold Publishers New York, 1953, $92-100$.

11. Onyenuga V A and Fetuga B L, J Sc Food Agric., 1975, 21, 843-854.

12. Al-Khalifa A S, J Agric Food Chem.,1996, 44(4), 964-966.

13. El-Adawy T E and Taha K M, J Agric Food Chem., 2001, 49(3), 1253-1259.

14. Egbekun M K, Nda-Suleiman E O and Akinyeye O, Foods Hum Nutr., 1998, 52(2), 171-176.

15. Divine $\mathrm{J}$ and William P N, The Chemistry and Technology of Edible Oils and Fats $1^{\text {st }}$ Ed., Pergamon Press, London, 1961, 127-138.

16. Nwinuka M N, Ogbonda J and Ayalogu E O, Glo J Pure Appl Sci., 2001, (7)3, 451-453.

17. Peters A O, West Afri J Bio Appl Chem., 1956, 14, 120.

18. Ekundayo C A and Idzi E, Plant Foods Hum Nutr., 1990, 40(3), 215-222.

19. Islam M N, Wilson C A and Watkins T R, J Agric Food Chem., 1982, 30(6), 1195-1198.

20. Osagie A U, Okoye W, Oluwayose B O and Dawndu A O, Nig J Appl Sci., 1986, 4, 151-162.

21. N I F O R,Nigeria Institute of Oil Research, History, Activities and Achievements $2^{\text {nd }}$ Edn. Benin City, Nigeria, 1989, 26 - 28.

22. Batel W, Graef M, Meyer GJ, Moller R, Schoedder F, Grund lagen der Landtechnic,1980, 30(2), 40-51. 


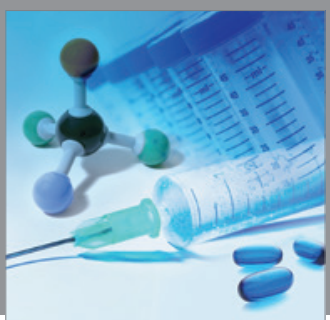

International Journal of

Medicinal Chemistry

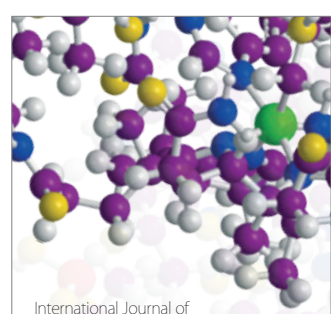

Carbohydrate Chemistry

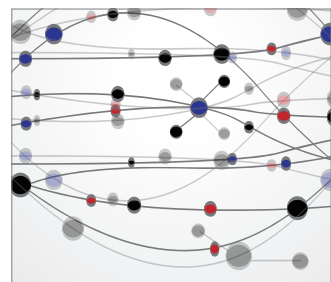

The Scientific World Journal
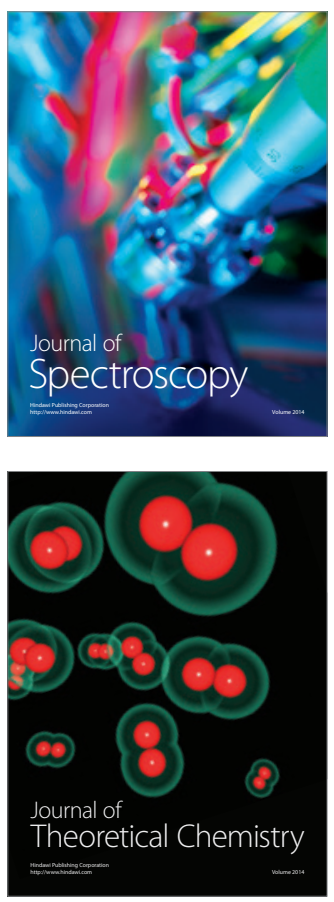
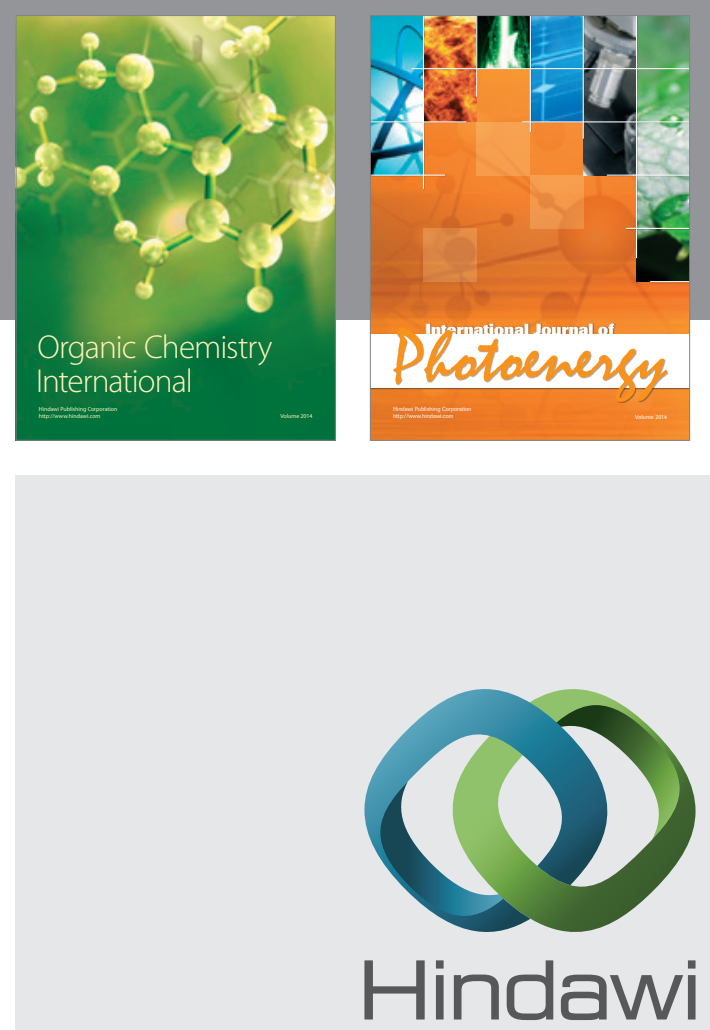

Submit your manuscripts at

http://www.hindawi.com
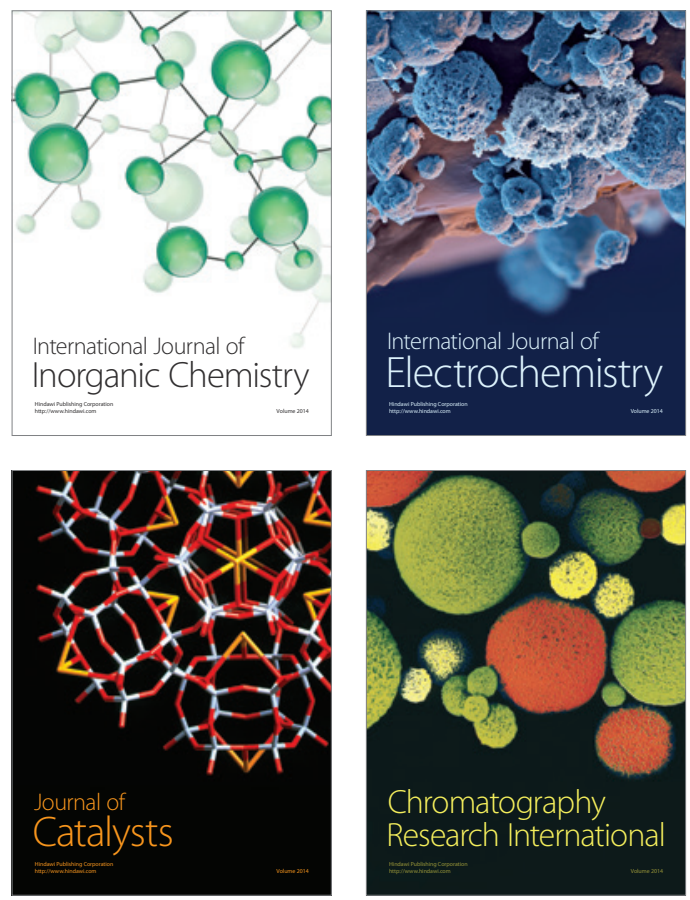
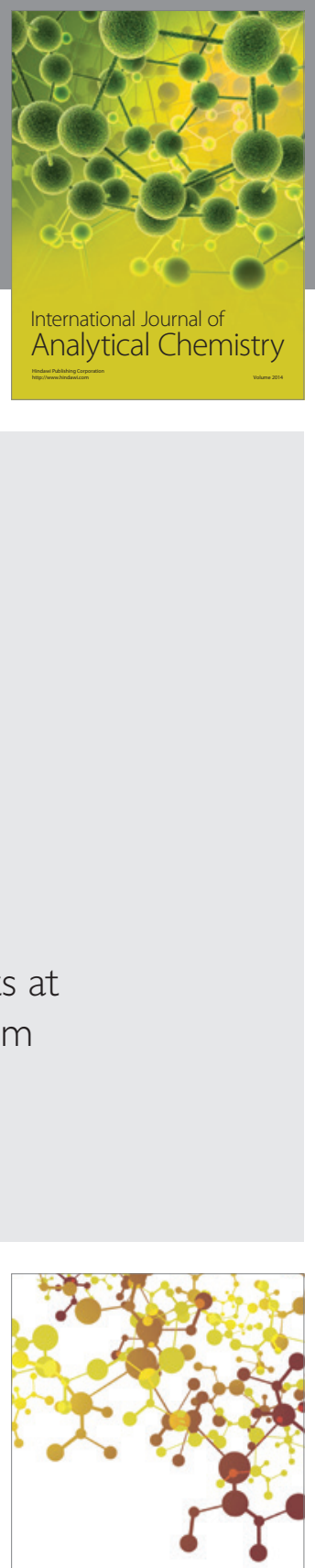

Journal of

Applied Chemistry
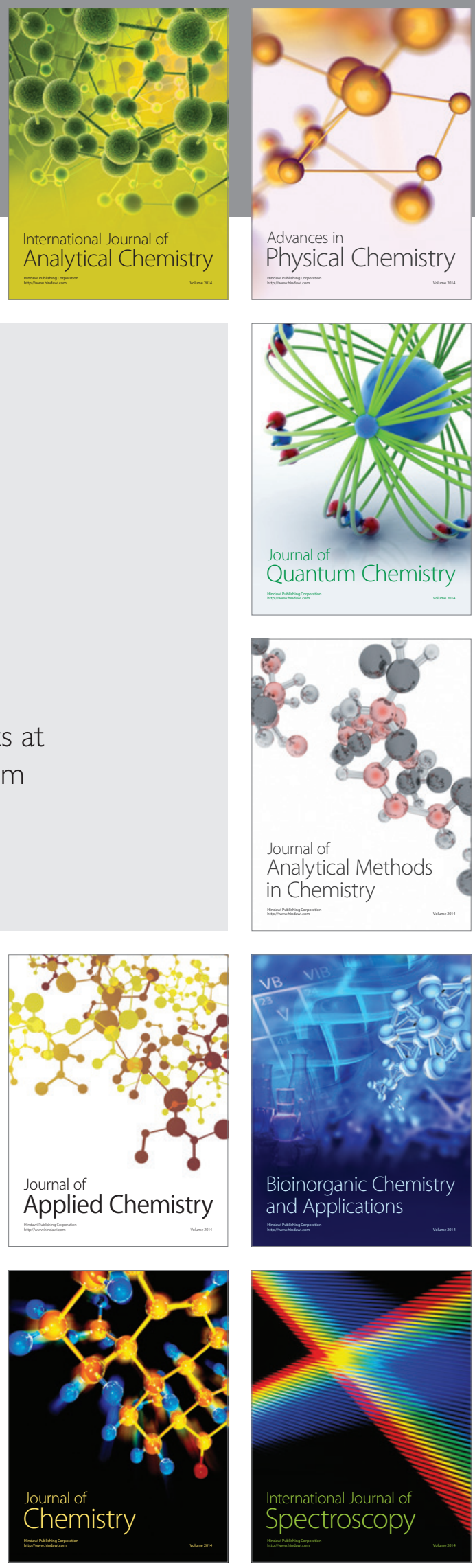